\section{Innovation, development, and financing of institutions of Higher Education in health}

\author{
Inovação, desenvolvimento e financiamento das \\ instituições de Ensino Superior em saúde
}

Innovación, desarrollo y financiación de las

instituciones de Enseñanza Superior en salud
Mario Roberto Dal Poz 1

Maria Helena Costa Couto 1

Thais de Andrade Vidaurre Franco 1

\begin{abstract}
The article analyzes the configuration and trends in institutions of Higher Education and their relationship as components of the Health EconomicIndustrial Complex (HEIC). The expansion of higher education is part of the transition from elite to mass systems, with tensions between quantitative and qualitative aspects. Such changes reflect different cultures and are related to international phenomena such as globalization, economic transformations, the development of new information and communication technologies, and the emergence of an international knowledge network. The scale and content of these changes vary according to the expansion and institutional reconfiguration of educational systems, as well as the link between state and society. Market expansion for private higher education stirs competition, shapes business clusters, modifies training processes, and raises new public policy challenges.
\end{abstract}

Higher Education Institutions; Government Financing; Public Policies; Sustainable Development; Innovation

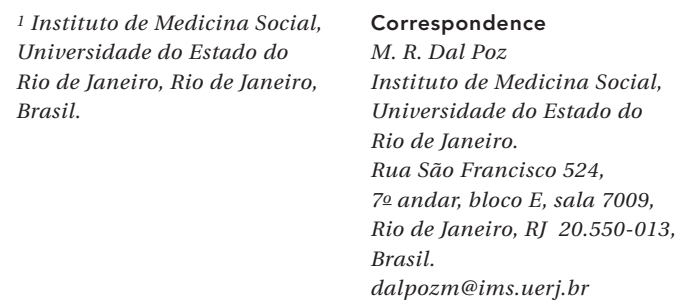




\section{Introduction}

Recent changes in Higher Education reflect different national cultures and relate closely to international phenomena such as globalization, economic transformations, development of new information and communication technologies, and the emergence of an international knowledge network 1,2 . Such changes take different shapes and intensities in scale and content and have launched processes of expansion in teaching systems and multiple institutional formats, as well as different links between state and society ${ }^{3}$. Examples include the internationalization of Higher Education, the brain drain, heightened competition, and massification of Higher Education.

In the internationalization of Higher Education, the development of policies and practices by academics, systems, and institutions are oriented to obtain new knowledge, commercial advantages, and increased global competitiveness 4 . The academic labor market has become increasingly globalized, creating an intense migratory flow of students, researchers, and faculty. An analysis in Thailand showed that the international services trade has affected the country's health system and health workforce 5 .

Academic migration patterns display a phenomenon known as the "brain drain", related to income inequalities a disproportional flow of researchers from South to North, resulting in important disadvantages for developing countries 1,6.

This process has heightened the competition between students for limited university admissions, and between institutions for status and especially for funding.

The expansion of Higher Education is part of the transition from elite systems to mass systems, or massification, a process rife with quantitativequalitative tensions. Although massification has expanded access, it has also had other effects, requiring an assessment of the nature and consequences of this expansion to reflect on its possible impacts on health training 2,4 .

Health training and the role of institutions of Higher Education are not unfamiliar to the health industry's dynamics. According to Cordeiro 7 and Albuquerque \& Campos 8 , the medical-industrial complex is shaped by the link between medical care, health training institutions (schools, universities), the pharmaceutical industry, and the medical device and diagnostic instrument manufacturing industry.

Currently known as the Health EconomicIndustrial Complex (HEIC), the health industry's dynamics involve the interdependence between industrial sectors and service provid- ers, joined by the health professions training institutions 9,10.

Assuming Cordeiro's 7 perspective, this article analyzes institutions of Higher Education and health training as components of the HEIC and agents of national economic development, with emphasis on innovation, expansion of access, privatization, and financing. According to Viana 11 (p. 62), the components of the HEIC (industry, services, and universities) include "private health plan operators, medical corporations, health maintenance organizations, and the health system's planning and public management levels [...]". Interactions between these industrial, financial, and services sectors "allow expanding the analysis of linkages between health innovation strategies and how they relate to the health sector's policy logic". Institutions of Higher Education are thus central to health training and the production, development, and validation of innovations in science and technology 12 .

Health systems face multiple workforce challenges. Growing recognition of these problems has sparked global initiatives emphasizing the scarcity and unequal distribution of health professionals as important elements in healthcare provision, even when supplies and equipment are available 13,14,15. As a result, the World Health Organization (WHO) and other agencies have called attention to the need for countries to invest in increasing their health workforce training capacities 16 .

The majority of the member states in the Organization for Economic Cooperation and Development (OECD) also experience workforce shortages in health services, compensating for them through international recruitment. Forecasts point to an widening gap between health workforce supply and demand 17 . Predicting increasing disproportionality due to population and health workforce aging, other countries face imbalances in skills: they produce too many new technicians and professionals in some areas, while other areas suffer shortages in skills sets or even lack of personnel in certain geographic areas $18,19,20$. Thus, regardless of national income (high, medium, or low), most countries must establish mechanisms and incentives to retain health workers in rural or remote regions in order to ensure equitable access. Strategies include opening new educational institutions, introduction of the practical training modality in rural settings, and quotas or scholarships for students from rural areas or small towns 21 .

As part of the global effort to explore and deal with challenges to increase the recruitment, training, and retention of healthcare personnel in developing countries and especially in the 
least developed nations, WHO published the World Health Report in 2006 13. The World Health Assembly then passed a resolution on the need to scale-up health workforce training, and together with partner institutions, it organized a taskforce to explore options for expanding health workforce education 22 .

During the centennial year of the Flexner Report 23 , an independent commission analyzed health training around the world and concluded that the current medical training model, consuming some 100 billion dollars a year worldwide, is fragmented, static, and inadequate 24 . The report provided the basis for global guidelines to transform and expand education and training of health professionals 14 . Still, the challenges for health training have become even more critical to the extent that universal coverage by national health systems was included in the post-2015 Sustainable Development Goals 25,26,27,28.

\section{Innovations and trends in health training}

Changes in Higher Education in health are intensified and fueled by health system issues like unequal distribution of health professionals, difficulty in retaining professionals in remote locations, a mismatch between medical education, health services, and the population's needs, and an on-going concern over quality, coupled with growing costs of professional training and education.

Rapid development and absorption of new healthcare technologies have impacts on health systems and require professionals to develop new skills and knowledge for adequate use of the available tools. This trend has also directed healthcare towards professional overspecialization. According to Camargo Jr. ${ }^{29}$, overspecialization mirrors progress in science and technology and stimulates society's medicalization. Healthcare has required joint action by different professionals and particularly those capable of quickly and efficiently tackling symptoms and illnesses, creating in patients the perceived (and not always real) need for a latest-generation diagnostic intervention. In this process, social, economic, and cultural factors lose their meaning and contribute to healthcare fragmentation and loss of perception of the human body's totality and complexity.

According to Godlee ${ }^{30}$, the harm from unnecessary health care or overtreatment produce unnecessary expenditures and overload health systems in countries like the United States, due to health professionals' malpractice insurance, rising costs, financial conflicts of interest, in- sufficient information, and erosion of patients' decision-making autonomy. These factors can combine with health workforce shortage to place greater pressure on institutions of Higher Education, revealing the limitations in their capabilities and opportunities for expanding or training their workforce. In this scenario, many institutions of Higher Education are limited in their ability to guarantee installations for appropriate clinical training. Critical difficulties include nonexistent or insufficient infrastructure and/ or equipment in medical schools or services and poorly qualified faculty and preceptors 31 . Technological innovations like simulated learning systems can provide realistic and flexible alternatives to traditional clinical training, contributing to skills development and relieving pressure on faculty ${ }^{32}$. Strategies to reduce healthcare costs and increase the efficiency and coverage of health and training systems feature disruptive innovation, telemedicine, and digital health 33 .

There is also a growing need to train new types of professionals, associated with the trend towards overspecialization, for example to deal with the accelerated and progressive population aging in higher income countries. Some countries have introduced new occupations, such as nurse clinicians, with duties in health promotion, diagnosis, and treatment of acute diseases and chronic conditions, and others. Especially low and middle income countries have invested in training community health workers and mobile technologies 34 .

Technological innovation and recent changes in epidemiological and demographic profiles, educational approaches, and health services functioning have a direct impact on health training, e.g., multidisciplinary teams and the development of new teaching formats ${ }^{35}$. An example of growing connectivity is e-learning, applied to undergraduate teaching to complement classroom education. Meanwhile, the multiplication of distance learning programs raises concerns over the quality of training, even as a facilitator of continuing professional development. Examples include the nurse training program in Kenya and the Pacific Open Learning Health Net (POLHN. World Health Organization. http://www.wpro. who.int/southpacific/programmes/pacific_ini tiatives/polhn/en/, accessed on 14/Jun/2015).

Despite advances and innovations in information technology, most countries lack trustworthy and complete data on professional health training institutions. The lack of information is worse in private teaching institutions, operating in an intensely dynamic market with the inauguration of new schools, mergers, acquisitions, and expansions. 
Brazil displays a sharp divide between the few institutions with academic and technological excellence, located in cities in the South and Southeast of the country, and a large contingent of institutions that scarcely meet minimum teaching standards and are incapable of conducting research and extension 36 .

Based on the Ministry of Education's National Student Performance Examination (ENADE), in $2010,50 \%$ of government medical schools scored greater than 4 (out of a maximum of 5), classified as high-quality. In 2013, $65.6 \%$ of the government schools scored 4 or 5 on the ENADE. Only $24 \%$ of private medical schools received these same scores. Meanwhile, $36 \%$ of private medical schools received the lowest scores ( 1 or 2), compared to only $4.5 \%$ of government schools. Government medical schools thus outperformed private schools again (Instituto Nacional de Estudos e Pesquisa Educacionais Anísio Teixeira. Exame Nacional de Desempenho dos Estudantes - ENADE. http://enadeies.inep.gov.br/enadeRe sultado/, accessed on 30/Nov/2015).

In addition, medical students in the Central and South of Brazil scored the highest marks, regardless of whether they were enrolled in government or private universities.

\section{Expansion of access to training and democratization of Higher Education}

In addition to the global trends mentioned above, Brazil has experienced a democratization of Higher Education, resulting from expansion in the enrollment of lower-income students, traditionally excluded from elite university training. This expansion has been made possible by affirmative action policies, state financing and subsidies, and new course modalities and formats. The expansion of access to Higher Education not only allows democratization and the promotion of equity and social justice, but also serves the market economy's purposes by turning students into consumers of "knowledge" as a service and product 37 .

The democratization of Higher Education in Brazil is quite complex, given the income inequality between families, disparities and gaps in pre-university schooling, and the reduced share of free, high-quality education 38 . Despite significant growth in total admissions and enrollment in absolute terms, Higher Education in Brazil is still insufficient and exclusionary, because lowincome students are still the minority in the most prestigious institutions and courses ${ }^{39}$. According to an analysis by the Brazilian Institute of Geography and Statistics (IBGE) 40 on average years of schooling according to per capita family income quintile, the largest proportional increase in schooling from 2004 to 2013 occurred in the lowest income quintile $(+45.9 \%)$. However, this increase in the poorest quintile reflects the fact that this population segment started with the lowest percentage in 2004.

Brazil also shows persistent inequalities based on race/color: of all white students 18 to 24 years of age, $69.4 \%$ were enrolled in university, as compared to only $40.7 \%$ of black and brown students 40 . The country also shows persistent regional differences. In 2013, the proportion of individuals 25 years or older with university degrees was $8.8 \%$ in the North of Brazil and $15.3 \%$ in the Southeast.

Access to Higher Education is still limited in Brazil when compared to OECD countries. In 2011, the proportion of Brazilians 25 years or older was $13 \%$, less than half the average for OECD (32\%) and G20 countries (27\%) 3.

In Brazil, the indicator usually used to evaluate access to Higher Education is the net university attendance rate among students 18 to 24 years of age. This indicator is influenced other schooling factors, such as the age-grade distortion in primary and secondary school, resulting in a large proportion either without access to Higher Education or enrolled after 24 years of age. One goal of the National Plan for Education 2001-2010 (PNE) was "to increase, by the end of the decade, the supply of Higher Education to at least $30 \%$ of the 18 to 24 -year age bracket" 41. However, in 2011 , only $14.9 \%$ of youth in this age group were enrolled in Higher Education; the figure reached $16.3 \%$ by 2013 , a proportion that Trow classified as the lower threshold of a mass university education system $40,42,43$.

According to Martin Trow 44 , systems of Higher Education in advanced societies are experiencing a historical transition that tends to involve three phases: the "elite system" with a maximum of $15 \%$ of the 18-24-year age group enrolled in Higher Education, with access exclusively on the basis of students' social class and family income; the second phase is the establishment of a "mass system", with $16 \%$ to $50 \%$ of the 18 -24-year age group enrolled, responding to demands and interests from a broader and more differentiated public coming from different social classes. The third phase is the establishment of a "universal access system", characterized by an enrollment rate of more than $50 \%$ in the 18 -24-year age group. 


\section{Privatization and growing costs of health education}

The expansion of Higher Education has been accompanied by a significant increase in training costs. In a context of major budget constraints and growing demand for access, increasing costs put heavy pressure on public budgets for education, especially in countries with a traditionally free and universal system of Higher Education.

Privatization of Higher Education is occurring around the world and specifically in Brazil. Although Brazil has some elite private universities, the private sector mostly serves a mass clientele and is not viewed as prestigious. It is classified as "demand-absorbing", that is, offering access to students unable to enter public universities, through a business model whose power is concentrated in the boards of directors, where the faculty have little influence and students are seen as consumers 2,45 .

Two modalities of privatization in Higher Education are interrelated and coexist in different countries and regions of the world: one involves a proportional increase in participation by private institutions in training, and the other with different mechanisms of privatization of public institutions, like cost-sharing, marketing services, consultancy, licensing, sale of intellectual property, rental of real estate, and collaboration with industry 2 .

China in 1997, the United Kingdom in 1998, and Austria in 2001 are examples of countries that traditionally maintained systems of free public Higher Education and that began to charge fees and/or tuition ${ }^{2}$.

Brazil, like Japan, South Korea, Philippines, Indonesia, and other Latin American and East Asian countries, has maintained a small, elitist, and selective public sector and has responded to pressures for increasing access by the expansion of private universities 2,43. In 2013, according to data from Anísio Teixeira Brazilian National Institute of Educational Studies and Research (INEP. Sinopse das estatísticas da educação superior. http://portal.inep.gov.br/superior-censosupe rior-sinopse, accessed on 01/Oct/2015), of the 2,391 higher institutions education in Brazil, 301 were public and 2,090 were private, or $87.41 \%$ of the total.

The increase in university enrollment in Brazil was fueled first by relative economic stability, rising income in the poorest populations groups, or according to Salm 46 , by inclusion of the poorest in consumption and credit. Next, various public financing mechanisms for private institutions of Higher Education contributed to a strong and rapid expansion of the sector.
The expansion of for-profit private universities was one of the most significant changes in Higher Education in Brazil, accompanied by transformations in their administrative and legal formats and the adoption of a market logic featuring managerial professionalization. The educational market's competitiveness has involved reducing the cost of training and favored the emergence of corporate groups with greater capacity to negotiate durable goods (equipment) and consumables, resulting in cost reductions and increasing profit margins 47,48 .

The opening of capital and the formation of oligopolies produced strong corporate groups through mergers and acquisitions. Despite the relative pulverization still characterizing Brazil's Higher Education market, this concentration of capital is occurring through the acquisition of financially strained small and medium-sized institutions or mergers that allow increasing gains, activity in new niches and regions, and growth in student enrollment and the number of courses 48,49,50.

The ease of these institutions in expanding their capital by publically trading their shares has produced unequal competition with nonprofit private universities. Open-capital Brazilian university groups feature Estácio Participações, Kroton Educacional, Sistema Educacional Brasileiro Participações S.A., and Laureate International Universities. The opening of capital by private universities indicates a process of financialization of the industry, leading to management changes, since business decisions are now made with a view towards shareholder market value 49 .

Anhanguera and Kroton merged in 2014, and the educational group became the 17th largest corporation on the São Paulo Stock Exchange (Bovespa) as measured by market value ${ }^{51}$. Although there are few open capital companies in education in Brazil, they represent a major share of enrollment and courses (Kroton, for example, has approximately one million undergraduate and graduate students).

Courses in the health professions have generally mirrored the overall trends in Higher Education, both in the significant expansion in the number of institutions and enrollment and the increase in private institutions' share in training these professionals, as shown in Figure 1.

Percentagewise, from 1991 and 2013, enrollment in public and private health courses grew by $372 \%$, proportionally higher than in Higher Education in general in Brazil (286\%). Although enrollment grew in public universities during this period, most of the increase occurred in course offerings and enrollment in private institutions. Private institutions' share of health 
Figure 1

Enrollment trends in undergraduate health courses in private and public universities. Brazil, 1991-2013.

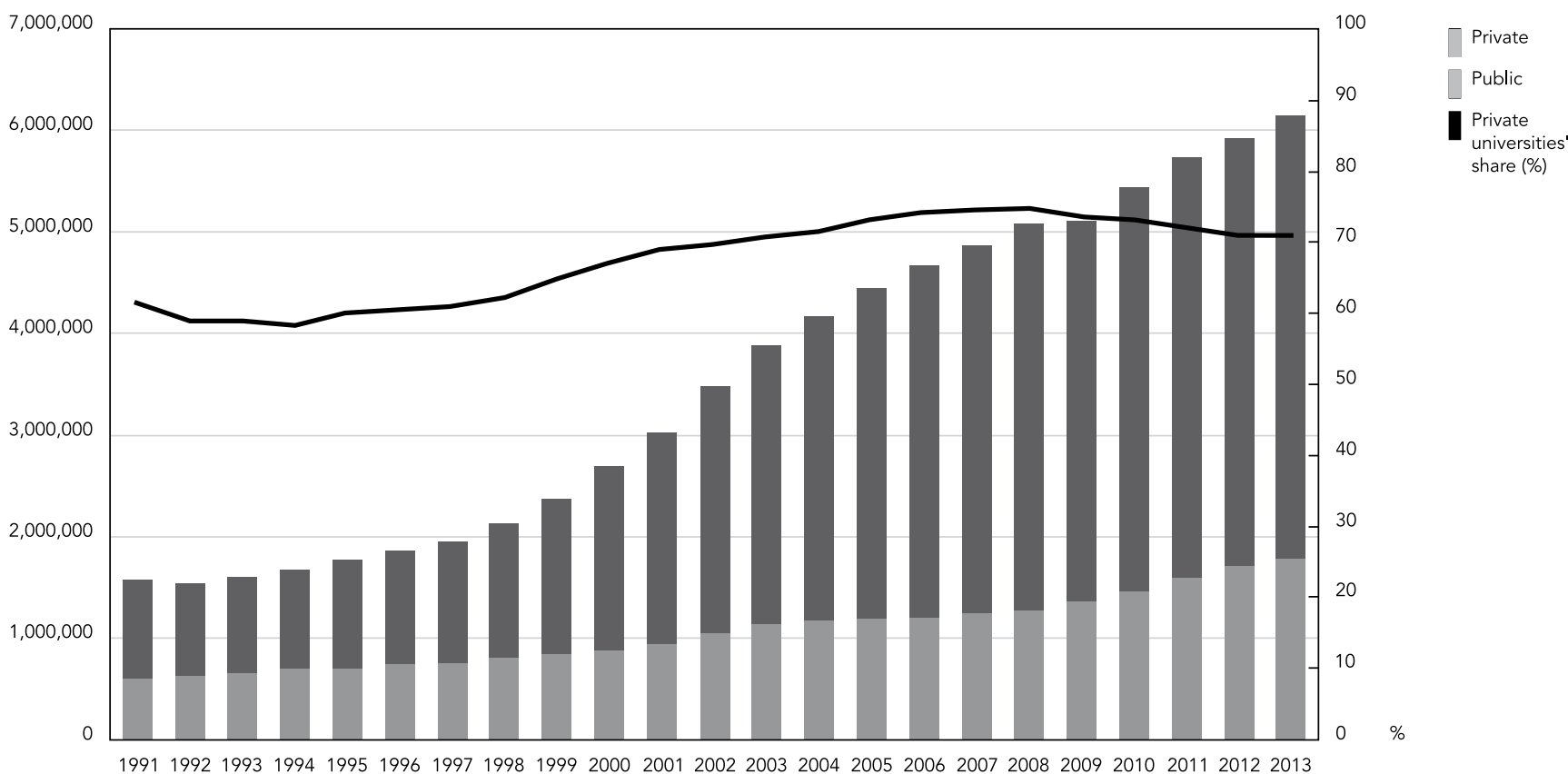

Source: prepared by the authors based on data from Anísio Teixeira Brazilian National Institute of Educational Studies and Research (INEP; http://www.inep. gov.br/, accessed on 30/Nov/2015) e Indicator System of Degrees in Health/Network Observatory of Human Resources in Health/Institute of Social Medicine/ Rio de Janeiro State University (SIGRAS/ObservaRH - IMS/UERJ; http://www.obsnetims.org.br/sigras/, accessed on 14/Jun/2015).

training increased from $55 \%$ in 1991 to $73 \%$ in 2013, while from 2006 to 2008 it peaked at $78 \%$ of enrollment in health courses.

The supply of private undergraduate health courses is still concentrated mainly in the South and Southeast. According to Corbucci 52, among other factors, this concentration is due to the large student demand fueled by the high population density and higher per capita income in the South and Southeast (compared to the rest of Brazil), resulting in higher profit margins in the market for Higher Education.

As shown in Figire 2, the distribution of private health courses is heavily concentrated in the Southeast Region.

Despite persistent regional disparities, from 1993 to 2013 there was a trend towards de-concentration of the supply of private courses, with an increase in the relative share of the North and Northeast Regions in the total course supply. In 1993, the Southeast had $66 \%$ of the country's courses, but by 2013 its share had decreased to $53 \%$. During this same period, the highest pro- portional growth in courses occurred in the North $(5,060 \%)$, Northeast $(2,170 \%)$, and CentralWest $(1,894 \%)$, which can be partially explained by the fact that these three regions had a low supply of courses in 1993. In the early 1990s, the private sector only predominated in the South and Southeast, with $51 \%$ and $64 \%$ of the health courses in those two regions, respectively. Since 2013, private undergraduate health courses have outnumbered public courses in every region of Brazil (INEP. Sinopse das estatísticas da educação superior. http://portal.inep.gov.br/superior-censosuperior-sinopse, accessed on 01/Oct/2015).

\section{Financing of private institutions of Higher Education in Brazil}

In recent decades, policies for incentivizing private institutions of Higher Education continued to be facilitated by direct and indirect financing mechanisms, incentives, and state subsidies to the private sector. In association with social 


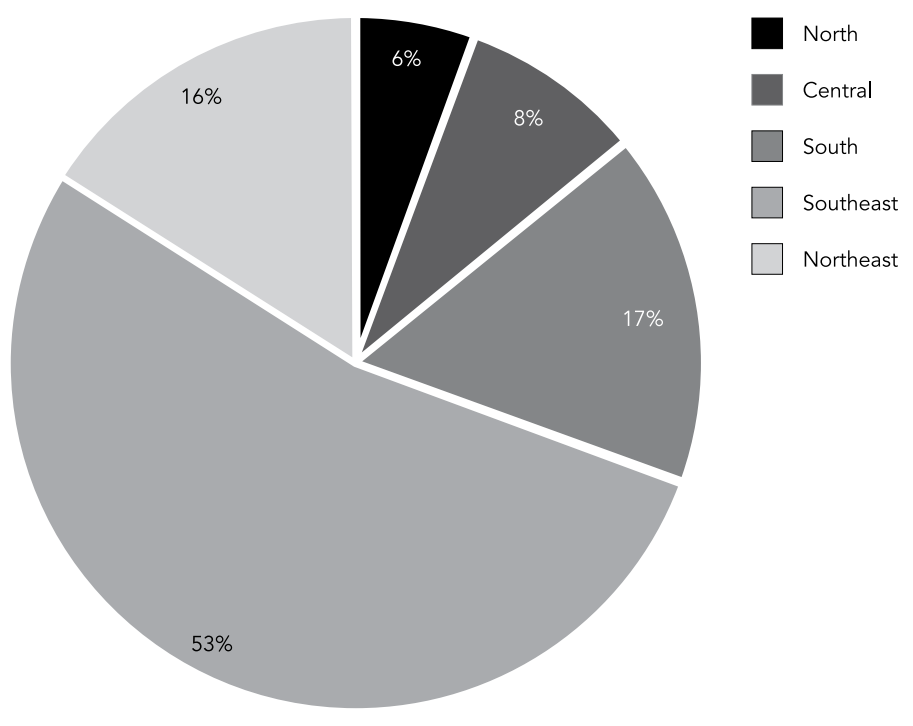

Source: prepared by the authors based on data from Anísio Teixeira Brazilian National Institute of Educational Studies and Research (INEP; http://www.inep.gov.br/, accessed on 30/Nov/2015) e Indicator System of Degrees in Health/Network Observatory of Human Resources in Health/Institute of Social Medicine/Rio de Janeiro State University (SIGRAS/ObservaRH IMS/UERJ; http://www.obsnetims.org.br/sigras/, accessed on 14/Jun/2015).

policies and financial subsidies, private Higher Education expanded in Brazil from 1995 to 2012 through enactment of the Law for Guidelines and Foundations in Education (LDB) in 1996, allowing more flexible course modalities, the creation of new universities, and the replacement of the unified national admissions examination ("vestibular") by simplified admissions, granting autonomy to private educational institutions for curriculum changes and facilitating non-compliance with the constitutional provision of 1988 on the inseparability between teaching, research, and extension 48 .

Although financing of private universities in Brazil depends largely on monthly tuition fees, the demand for Higher Education has been incentivized by federal programs through direct and indirect public resources such as programs for the recovery, expansion, and improvement of institutions of Higher Education and the fund for financing university students.

In 1997, the National Economic and Social Development Bank (BNDES), in partnership with the Brazilian Ministry of Education, provided financing through the Program for the Improvement of Training in Institutions of Higher
Education, for infrastructure modernization and expansion, purchase of equipment and software, staff training, and organizational and financial restructuring. In the first 10 years, this program funded 61 projects at 48 institutions, predominantly in the private sector. In the second stage, from 2009 to 2014, funding for private universities (both for-profit and non-profit) was conditioned on adherence to the Fund for Financing Students in Higher Education (FIES), the University for All Program (ProUni), and the Student Loan Underwriting Fund (FGEDUC) 53,54,55.

Established in 1999 to replace the Student Loan Program (PCE), FIES consists of funds from the National Lottery and the Ministry of Education's budget. It funds up to $100 \%$ of the tuition charged to students in private universities, with a positive evaluation by the Brazilian Ministry of Education. Beginning in 2007, funding has been expanded to include Master's and PhD courses, and in 2011 to vocational and technical courses $56,57,58,59$.

Since its creation, FIES has undergone various changes through rulings, provisional measures, laws, decrees, and amendments. Since 2005, FIES has also granted partial scholarships 
(50\%) to undergraduate students selected for the ProUni.

The most significant changes in FIES occurred in 2010, transferring the fund's management from the Caixa Econômica Federal (Federal Savings and Loan Bank) to the National Fund for the Development of Education (FNDE), a cut in interest rates from $6.5 \%$ to $3.4 \%$ per year, and write-offs on the balance due for public schoolteachers and family health physicians in priority areas set by the Ministry of Health. The changes also involved more flexible rules on student loan underwriting and extended amortization, thereby significantly increasing the number of financial aid contracts, as shown in Figure 3.

From 2010 to 2014 , there was a $735 \%$ increase in the number of financial aid contracts, and the cost of the program for the government increased 17-fold, from $\mathrm{R} \$ 810$ million in 2010 to $\mathrm{R} \$ 13.75$ billion in 2014. Meanwhile, FIES student loans provide an indirect subsidy to private universities by reducing the default risk. The credit risk was attenuated even further in 2009, when the government created the Student Loan Underwriting Fund (FGEDUC), thereby assuming the role of underwriter and final guarantor for students' personal debts $56,57,58,59$.
Prevailing financial aid contracts or those signed before April 2015 may have encouraged the entry into the program of students that could afford to pay their monthly tuition themselves, since with interest rates below inflation, future amortization payments would be cheaper than current tuition. Such rules led to strong growth in financial transfers to corporate groups in the education industry. In December 2014, the Brazilian Ministry of Education issued a ruling that restricted access to the program, and since 2015 the Ministry has required a minimum score of 450 on the National Middle School Examination (ENEM).

After publishing restrictions on access to the FIES by students with low performance, the Brazilian Ministry of Education issued a new ruling altering the timetable for repurchase of bonds from the program of the National Fund for the Development of Education (FNDE). Investors responded by selling securities in the education industry. According to the rules, the FNDE trades cash for the Treasury-certified securities, offered to the companies when students sign their financial aid contracts with FIES.

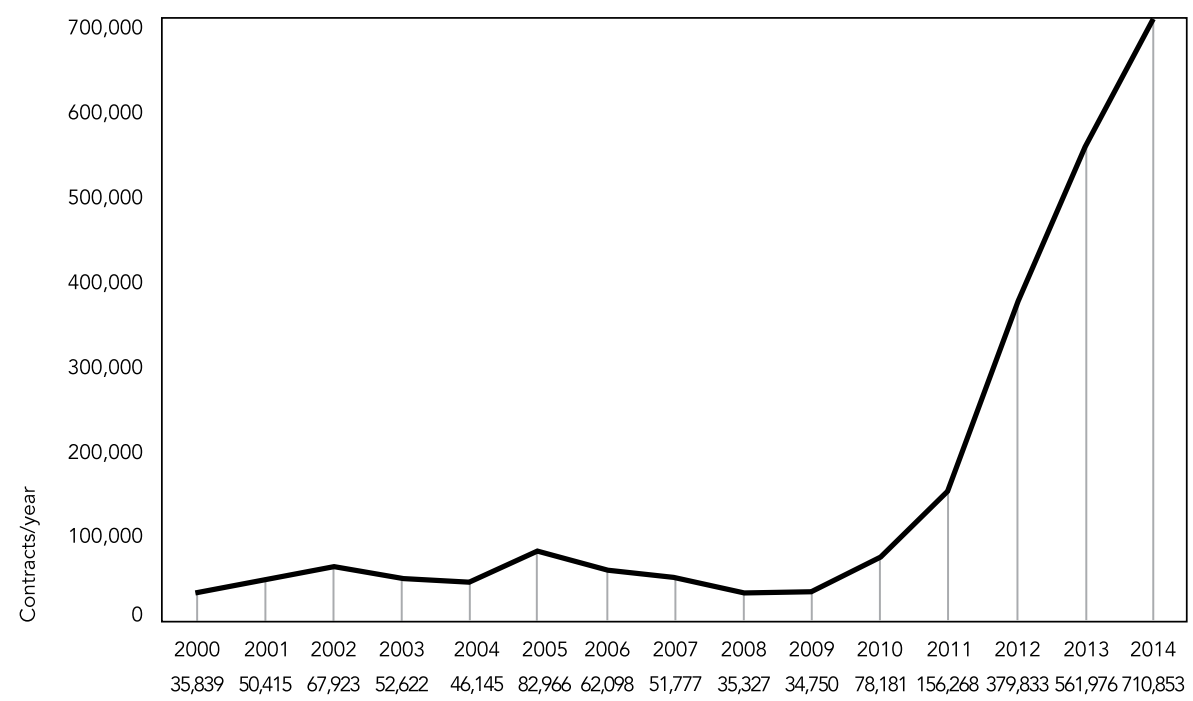

Source: prepared by the authors based on data from the Federal Government Platform of Indicators (http://dados.gov.br/ dataset/fies-fundo-de-financiamento-estudantil, accessed on 30/Nov/2015). 
New changes as of April 2015 aim to strengthen the program's medium-term sustainability. Contracts now set a new interest rate and a cap on per capita family income.

In 2004, three groups of stakeholders, the publicists, privatists, and a third group that defended dual financing for university education, dispute the discussion and designing the ProUni. The program awarded tax exemptions to forprofit private universities that provided scholarships to one out of every nine students and to non-profit private universities that gave scholarships to one out of four students. In addition to per capita family income, the eligibility criteria for ProUni students to apply for scholarships are: having taken the ENEM and having finished secondary school. When it was implemented, the program did not require that the supply of scholarships be proportional to all the courses and shifts, which favored concentration of financial aid in the cheapest courses and those with the least competition. The rule was changed in 2013, when Law 12,868 59 established the mandatory supply of scholarships in all the courses and shifts.

Despite widespread acknowledgement of the role of ProUni in expanding access to Higher Education, its effectiveness in promoting social justice has been questioned, since the program guarantees better financial conditions for private universities, without requiring investment in either quality expansion of enrollment or ensuring low-income students' retention and course conclusion 38,55 .

The year 2012 witnessed the creation of the Program for Stimulus to Restructuring and Strengthening of Institutions of Higher Education (Proies) for rescheduling or pardoning the federal tax debts of financially strained private universities and enabling them to grant scholarships 60 .

As discussed by several authors, the policy for expansion of Higher Education in Brazil has favored the private sector through government incentives, especially the ProUni and FIES programs 61,62

\section{Conclusions}

The rapid development and absorption of new health technologies have impacts on the health and education systems, as well as on the medical equipment, inputs, and services industry, requiring new professional skills and enhanced market dynamics.

However, most national health systems still face challenges in workforce training, retention, and management, besides critical difficulties in overcoming regional inequalities and delivering adequate services for the population's demands and needs.

The 1990s saw numerous global and national initiatives to deal with the problems and challenges of training healthcare professionals to meet the population's needs and guarantee quality of care.

Expansion of the private market in Higher Education brought competition and resulted in large corporate groups, which included publically trading their shares, with impacts on training that have still received little attention by researchers, besides increasing the challenges for public policies, particularly on regulatory issues.

The expansion of private universities (especially for-profit) has been boosted by public financing mechanisms such as tax exemptions, direct funding, and subsidized student loans. However, this expansion in enrollment is still insufficient and relatively exclusionary.

Participation by the private sector attracted new stakeholders and institutions to health training. In addition, the expansion of health training has not been accompanied by effective regulatory mechanisms for reducing imbalances between supply and demand or the regional inequalities in the health labor market.

Lack of information and knowledge on the dynamics and privatization and expansion of health training is limits the analysis and should serve to encourage the elaboration of a research agenda combining identification of problems and production of knowledge in order for the problems identified thereby to become priorities on the national policy agenda.

In addition to evaluating and monitoring the results of policies to incentivize various aspects of health workforce development, including distribution and retention, curriculum reform is crucial in the current context, as is analysis of the reorientation of institutions of Higher Education and the dynamics of the health system in Brazil, besides the feasibility and sustainability of inaugurating new medical schools and the capacity to train new medical professionals, linking teaching and services.

This article has addressed the importance and characteristics of current changes in Higher Education in health, identifying trends in private universities participating in health training and discussing interaction between public policies for health training and private universities. Knowledge output in this field can shed light on challenges and contradictions in the regulation of education and health systems, linked to the HEIC and national economic development. 


\section{Contributors}

M. R. Dal Poz participated in the organization, writing, and revision of the article, data analysis and interpretation, and final responsibility for all aspects of the study, guaranteeing the accuracy and integrity of the final version. M. H. C. Couto and T. A. V. Franco contributed in the organization, writing, and revision of the article, data analysis and interpretation, and approval of the final version.

\section{Acknowledgments}

To Brazilian National Research Council (Research Project n. 405077/2013-0); Rio de Janeiro State Research Foundation (FAPERJ) and Incentive Program Scientific Production, Technical and Artistic of the Rio de Janeiro State University (Prociência/UERJ) for the Support and funding.

\section{References}

1. Altbach PG, Reisberg L, Rumbley LE. Trends in global higher education: tracking an academic revolution. Paris: Organisation des Nations Unies pour l'education, la science et la culture; 2009.

2. Stromquist NP. Latin America's education in globalized times. Sociologias 2012; 14:72-99.

3. Organization for Economic Cooperation and Development. Education at a glance 2014: OECD indicators. Paris: OECD Publishing; 2014.

4. Altbach PG, Knight J. The internationalization of higher education: motivations and realities. J Intern Educ 2007; 11:290-305.

5. Wibulpolprasert S, Pachanee C, Pitayarangsarit S, Hempisut $P$. International service trade and its implications for human resources for health: a case study of Thailand. Hum Resour Health 2004; 2:10.

6. Schwartzman J, Schwartzman S. O ensino superior privado como setor econômico. Avaliação de Políticas Públicas em Educação 2002; 10:405-560.

7. Cordeiro H. A indústria de saúde no Brasil. Rio de Janeiro: Edições Graal; 1980.

8. Campos FE, Albuquerque EM. As especificidades contemporâneas do trabalho no setor saúde: notas introdutórias para uma discussão. Belo Horizonte: Centro de Desenvolvimento e Planejamento Regional, Universidade Federal de Minas Gerais; 1998. (Texto para Discussão, 123).
9. Costa L, Gadelha CAG, Maldonado J, Santo M Metten A. O complexo produtivo da saúde e sua articulação com o desenvolvimento socioeconômico nacional. Revista do Serviço Público 2013; 64:177-99.

10. Gadelha CAG. O complexo industrial da saúde e a necessidade de um enfoque dinâmico na economia da saúde. Ciênc Saúde Coletiva 2003; 8:521-35.

11. Viana ALd'A, Iozzi FL, Albuquerque MV, Bousquat A. Saúde, desenvolvimento e inovação tecnológica: nova perspectiva de abordagem e de investigação. Lua Nova 2011; 83:41-77.

12. Albuquerque E, Cassiolato J. As especificidades do sistema de inovação do setor saúde: uma resenha da literatura como introdução a uma discussão sobre o caso brasileiro. São Paulo: Federação de Sociedades de Biologia Experimental; 2000. (Estudos FeSBE I).

13. World Health Organization. World Health Report 2006: working together for health. Geneva: World Health Organization; 2006.

14. World Health Organization. Transforming and scaling up health professionals' education and training: WHO Education Guidelines 2013. Geneva: World Health Organization; 2013. 
15. Global Health Workforce Alliance. The Recife Political Declaration on Human Resources for Health: renewed commitments towards universal health coverage. http://www.who.int/workforcealliance/ forum/2013/3gf_finaldeclaration/en/ (accessed on $14 /$ Jun/2015).

16. Crisp N, Gawanas B, Sharp I. Training the health workforce: scaling up, saving lives. Lancet 2008; 371:689-91.

17. Ono T, Lafortune G, Schoenstein M. Health Workforce Planning in OECD Countries: a review of 26 projection models from 18 countries. Paris: OECD Publishing; 2013. (OECD Health Working Papers, 62).

18. Dussault G, Franceschini MC. Not enough there, too many here: understanding geographical imbalances in the distribution of the health workforce. Humn Resourc Health 2006; 4:12.

19. Assunção AA, Belisário SA, Campos FE, D’Ávila S. Recursos humanos e trabalho em saúde: os desafios de uma agenda de pesquisa. Cad Saúde Pública 2007; 23 Suppl 2:S193-201.

20. Dal Poz MR. A crise da força de trabalho em saúde. Cad Saúde Pública 2013; 29:1924-6.

21. Word Health Organization. Increasing access to health workers in remote and rural areas through improved retention: global policy recommendations. Geneva: World Health Organization; 2010.

22. Global Health Workforce Alliance. Scaling up, saving lives: task force for scaling up education and training for health workers. Geneva: World Health Organization; 2008.

23. Flexner A. Medical education in the United States and Canada. Washington DC: Science and Health Publications; 1910.

24. Frenk J, Chen L, Bhutta ZA, Cohen J, Crisp N, Evans $\mathrm{T}$, et al. Health professionals for a new century: transforming education to strengthen health systems in an interdependent world. Lancet 2010; 376:1923-58.

25. Buse K, Hawkes S. Health in the sustainable development goals: ready for a paradigm shift? Global Health 2015; 11:13-21.

26. United Nation. The road to dignity by 2030: ending poverty, transforming all lives and protecting the planet. Synthesis report of the Secretary-General on the post-2015 agenda. New York: United Nations; 2014.

27. World Health Organization. Positioning health in the post-2015 development agenda. Geneva: World Health Organization; 2012. (WHO Discussion Paper).

28. World Bank Group. Financing for development post-2015. Washington DC: World Bank Group; 2013.

29. Camargo Jr. KR. Biomedicina, saber \& ciência: uma abordagem crítica. São Paulo: Editora Hucitec; 2003.

30. Godlee F. Overtreatment, over here. BMJ 2012; 345:e6684

31. Chaves LJ, Gonçalves ECQ, Ladeira LR, Ribeiro MS, Costa MB, Ramos AAM. A tutoria como estratégia educacional no ensino médico. Rev Bras Educ Méd 2014; 38:532-41
32. Adler MS, Gallian DMC. Formação médica e serviço único de saúde: propostas e práticas descritas na literatura especializada. Rev Bras Educ Méd 2014; 38:388-96.

33. Christensen CM, Bohmer R, Kenagy J. Will disruptive innovations cure health care? Harv Bus Rev 2000; 78:102-12.

34. Tulenko K, Mogedal S, Afzal MM, Frymus D, Oshin A, Pate M, et al. Community health workers for universal health-care coverage: from fragmentation to synergy. Bull World Health Organ 2013; 91:847-52.

35. Reeves S, Zwarenstein M, Goldman J, Barr H, Freeth D, Hammick M, et al. Interprofessional education: effects on professional practice and health outcome (update). Cochrane Database Syst Rev 2013; (23):CD002213.

36. Dal Poz MR, Varella TC, Santos RM. Formação em saúde: problemas e tendências. Rio de Janeiro: Fundação Oswaldo Cruz; 2015.

37. Dias Sobrinho J. Educação superior: bem público, equidade e democratização. Avaliação: Revista da Avaliação da Educação Superior 2013; 18:107-26.

38. Carvalho CHA. O ProUni no governo Lula e o jogo político em torno do acessado ao ensino superior. Educação \& Sociedade 2006; 27:979-1000.

39. Vonbun C, Mendonça JLO. Educação superior uma comparação internacional e suas lições para o Brasil. Brasília: Instituto de Pesquisa Econômica Aplicada; 2012. (Texto para Discussão, 1720).

40. Instituto Brasileiro de Geografia e Estatística. Síntese de indicadores sociais: uma análise das condições de vida da população brasileira 2014. Rio de Janeiro: Instituto Brasileiro de Geografia e Estatística; 2014

41. Presidência da República. Lei no 10.172, de 9 de janeiro de 2001. Aprova o Plano Nacional de Educação e dá outras providências. Diário Oficial da União 2001; 10 jan.

42. Trow M. Reflections on the transition from elite to mass to universal access: forms and phases of higher education in modern societies since WWII. Berkeley: Institute of Governmental Studies; 2005.

43. Gomes AM, Moraes KN. Educação superior no Brasil contemporâneo: transição para um sistema de massa. Educação \& Sociedade 2012; 33:171-90.

44. Trow M. Problems in the transition from elite to mass higher education. In: Policies for Higher Education, Conference on Future Structures of Post-Secondary Education. Paris: Organisation for Economic Co-operation and Development; 1973. p. 55-101.

45. Garcia M. Três grandes tendências para o ensino superior privado no Brasil. Revista do Ensino Superior 2005; 77:41-3.

46. Salm C. Estagnação econômica, desemprego e exclusão social. In: Sicsú J, Paula LF, Michel R, organizadores. Novo desenvolvimentismo: um projeto nacional de crescimento com equidade social. Barueri: Edições Manole/Rio de Janeiro: Fundação Konrad Adenauer; 2005. p. 217-37. 
47. Gaspar RF, Fernandes TC. Mercantilização e oligopolização no ensino superior privado. Educação \& Realidade 2014; 39:945-66.

48. Chaves VLJ. Expansão da privatização/mercantilização do ensino superior brasileiro: a formação dos oligopólios. Educação \& Sociedade 2010; 31:481-500.

49. Carvalho CHA. A mercantilização da educação superior brasileira e as estratégias de mercado das instituições lucrativas. Rev Bras Educ 2013; 18: 761-801.

50. Sguissardi V. Regulação estatal e desafios da expansão mercantil da educação superior. Educação \& Sociedade 2013; 34:943-60.

51. Tuon L. Valor da Kroton na bolsa salta nove posições após compra da Anhanguera. http://www. valor.com.br/empresas/3604836/valor-da-krotonna-bolsa-salta-nove-posicoes-apos-compra-da-a nhanguera (acessado em 04/Mai/2015).

52. Corbucci, PR. Desafios da educação superior e desenvolvimento no Brasil. Brasília: Instituto de Pesquisa Econômica Aplicada; 2007. (Texto para Discussão, 1287).

53. Sécca RX, Leal RM. Análise do setor de ensino superior privado no Brasil. BNDES Setorial 2009; 30:103-56.

54. Guimarães ALS, Leal RM, Lima JCCO, SéccaRX, Menezes NML. O financiamento do BNDES ao ensino superior: uma avaliação dos impactos do primeiro Programa IES-BNDES. Revista do BNDES 2010; 33:55-80.

55. Souza MRA, Menezes M. Programa Universidade para Todos (ProUni): quem ganha o quê, como e quando? Avaliação de Políticas Públicas em Educação 2014; 22:609-33.

56. Brasil. Lei ํo 11.552, de 19 de novembro de 2007. Altera a Lei no 10.260 , de 12 de julho de 2001, que dispõe sobre o Fundo de Financiamento ao Estudante do Ensino Superior - FIES. Diário Oficial da União 2007; 20 nov.

57. Brasil. Lei no 12.513 , de 26 de outubro de 2011. Institui o Programa Nacional de Acessado ao Ensino Técnico e Emprego (Pronatec); altera as Leis no 7.998, de 11 de janeiro de 1990, que regula o Programa do Seguro-desemprego, o Abono Salarial e institui o Fundo de Amparo ao Trabalhador (FAT), no 8.212, de 24 de julho de 1991, que dispõe sobre a organização da Seguridade Social e institui Plano de Custeio, no 10.260, de 12 de julho de 2001, que dispõe sobre o Fundo de Financiamento ao Estudante do Ensino Superior, e no 11.129, de 30 de junho de 2005, que institui o Programa Nacional de Inclusão de Jovens (ProJovem); e dá outras providências. Diário Oficial da União 2011; 27 out.
58. Brasil. Lei no 12.202, de 14 de janeiro de 2010. Altera a Lei no 10.260 , de 12 de julho de 2001, que dispõe sobre o Fundo de Financiamento ao Estudante do Ensino Superior - FIES (permite abatimento de saldo devedor do FIES aos profissionais do magistério público e médicos dos programas de saúde da família; utilização de débitos com o INSS como crédito do FIES pelas instituições de ensino; e dá outras providências). Diário Oficial da União 2010; 15 jan.

59. Brasil. Lei no 12.868, de 15 de outubro de 2013. Altera a Lei no 12.793, de 2 de abril de 2013, para dispor sobre o financiamento de bens de consumo duráveis a beneficiários do Programa Minha Casa, Minha Vida (PMCMV); constitui fonte adicional de recursos para a Caixa Econômica Federal; altera a Lei no 12.741, de 8 de dezembro de 2012, que dispõe sobre as medidas de esclarecimento ao consumidor, para prever prazo de aplicação das sanções previstas na Lei no 8.078, de 11 de setembro de 1990; altera as Leis no 12.761 , de 27 de dezembro de 2012, no 12.101, de 27 de novembro de 2009, no 9.532, de 10 de dezembro de 1997, e no 9.615, de 24 de março de 1998; e dá outras providências. Diário Oficial da União 2013; 16 out.

60. Brasil. Lei no 12.688, de 18 de julho de 2012. Conversão da Medida Provisória no 559, de 2012. Autoriza a Centrais Elétricas Brasileiras S.A. (Eletrobras) a adquirir o controle acionário da Celg Distribuição S.A. (Celg D); institui o Programa de Estímulo à Reestruturação e ao Fortalecimento das Instituições de Ensino Superior (Proies); altera as Leis no 3.890-A, de 25 de abril de 1961, 9.718 , de 27 de novembro de 1998, 10.637, de 30 de dezembro de 2002, 10.887, de 18 de junho de 2004, 10.833, de 29 de dezembro de 2003, 11.033, de 21 de dezembro de 2004, 11.128, de 28 de junho de 2005, 11.651, de 7 de abril de 2008, 12.024, de 27 de agosto de 2009, 12.101, de 27 de novembro de 2009, 12.429, de 20 de junho de 2011, 12.462, de 4 de agosto de 2011, e 12.546, de 14 de dezembro de 2011; e dá outras providências. Diário Oficial da União 2012; 19 jul.

61. Mancebo D, Vale AA. Expansão da educação superior no Brasil e a hegemonia privado-mercantil: o caso da Unesa. Educação \& Sociedade 2013; 34:81-98.

62. Gemaque RMO, Chaves VLJ. Perfil da expansão no setor público e privado e financiamento da educação superior brasileira pós-LDB. Periódico do Mestrado em Educação da UCDB 2010; (30):71-91. 


\section{Resumo}

Este artigo analisa a configuração e as tendências das instituições de Ensino Superior de saúde no seu relacionamento enquanto componentes do Complexo Econômico Industrial da Saúde (CEIS). A expansão do Ensino Superior é parte da transição de sistemas de elite para sistemas de massa, com tensionamentos entre aspectos quantitativos e qualitativos. Essas mudanças refletem diferentes culturas e se relacionam com fenômenos de escopo mundial como globalização, transformações econômicas, desenvolvimento de novas tecnologias de comunicação e informação, e emergência de uma rede internacional de conhecimento. A escala e o conteúdo dessas mudanças variam com a ampliação dos sistemas de ensino e na reconfiguração institucional, bem como na articulação entre Estado e sociedade. A ampliação do mercado privado no ensino acirra a competitividade, conformando conglomerados empresariais, alterando processos de formação e forjando novos desafios para as políticas públicas.

Instituições de Ensino Superior; Financiamento Governamental; Políticas Públicas; Desenvolvimento Sustentável; Inovação

\section{Resumen}

Este artículo analiza la configuración y las tendencias de las instituciones de Enseñanza Superior de salud, en su relación como componentes del Complejo Económico Industrial de la Salud (CEIS). La expansión de la enseñanza superior es parte de la transición de sistemas de élite hacia sistemas de masa, con tensiones entre aspectos cuantitativos y cualitativos. Estos cambios reflejan diferentes culturas y se relacionan con fenómenos de alcance mundial como: la globalización, transformaciones económicas, desarrollo de nuevas tecnologías de comunicación e información, y emergencia de una red internacional de conocimiento. La escala y el contenido de esos cambios varían con la ampliación de los sistemas de enseñanza y en la reconfiguración institucional, así como en la articulación entre Estado y sociedad. La ampliación del mercado privado en la enseñanza estimula la competitividad, conformando conglomerados empresariales, alterando procesos de formación y forjando nuevos desafios para las políticas públicas.

Instituciones de Enseñanza Superior; Financiación Gubernamental; Políticas Públicas;

Desarrollo Sostenible; Innovación
Submitted on 28/Aug/2015

Final version resubmitted on $08 / \mathrm{Dec} / 2015$ Approved on 18/Feb/2015 